\title{
Surface Structure and Catalytic Performance of Ni-Fe Catalyst for Low-Temperature CO Hydrogenation
}

\author{
Fanhui Meng, Pengzhan Zhong, Zhong Li, Xiaoxi Cui, and Huayan Zheng \\ Key Laboratory of Coal Science and Technology, Ministry of Education and Shanxi Province, Taiyuan University of Technology, \\ Taiyuan, Shanxi 030024, China \\ Correspondence should be addressed to Zhong Li; lizhong@tyut.edu.cn
}

Received 6 December 2013; Revised 19 February 2014; Accepted 21 February 2014; Published 24 March 2014

Academic Editor: Anton Kokalj

Copyright (C) 2014 Fanhui Meng et al. This is an open access article distributed under the Creative Commons Attribution License, which permits unrestricted use, distribution, and reproduction in any medium, provided the original work is properly cited.

Catalysts $16 \mathrm{Nix} F \mathrm{Fe} / \mathrm{Al}_{2} \mathrm{O}_{3}(x$ is $0,1,2,4,6,8)$ were prepared by incipient wetness impregnation method and the catalytic performance for the production of synthetic natural gas $(\mathrm{SNG})$ from $\mathrm{CO}$ hydrogenation in slurry-bed reactor were studied. The catalysts were characterized by BET, XRD, UV-Vis DRS, $\mathrm{H}_{2}$-TPR, CO-TPD, and XPS, and the results showed that the introduction of iron improved the dispersion of $\mathrm{Ni}$ species, weakened the interaction between $\mathrm{Ni}$ species and support and decreased the reduction temperature and that catalyst formed $\mathrm{Ni}-\mathrm{Fe}$ alloy when the content of iron exceeded $2 \%$. Experimental results revealed that the addition of iron to the catalyst can effectively improve the catalytic performance of low-temperature $\mathrm{CO}$ methanation. Catalyst $16 \mathrm{Ni} 4 \mathrm{Fe} / \mathrm{Al}_{2} \mathrm{O}_{3}$ with the iron content of $4 \%$ exhibited the best catalytic performance, the conversion of $\mathrm{CO}$ and the yield of $\mathrm{CH}_{4}$ reached $97.2 \%$ and $84.9 \%$, respectively, and the high catalytic performance of $\mathrm{Ni}$-Fe catalyst was related to the property of formed Ni-Fe alloy. Further increase of iron content led to enhancing the water gas shift reaction.

\section{Introduction}

The production of synthetic natural gas (SNG) from coal or biomass has attracted much attention in recent years, especially in China, because of the increasing demands for natural gas and the wish for enhancing domestic energy security $[1,2]$. The gasification of coal results in the production of syngas containing mainly $\mathrm{H}_{2}$ and $\mathrm{CO}$; after the gas cleaning, the $\mathrm{H}_{2} / \mathrm{CO}$ ratio of the syngas can be adjusted to suitable ratio by water-gas shift reaction (WGSR) and finally the syngas can be converted to SNG through CO methanation. Among the SNG production processes, the methanation of syngas is one of the most critical steps, and the methanation reaction is a strong exothermic reaction; for every $1 \%$ of $\mathrm{CO}$ completely converted into $\mathrm{CH}_{4}$, gas adiabatic temperature rise is approximately $70^{\circ} \mathrm{C}$ [3]. Thus, the major challenge is to remove in time the highly exothermic heat effectively. Recently, many efforts have been made to develop a number of methanation reactors for SNG production, including fixed-bed $[1,4]$, fluidized-bed [5-7], and slurrybed reactors $[8,9]$. Among them, the slurry-bed reactor can remove the reaction heat efficiently and keep the reaction at isotherm low temperature so as to minimize the catalyst deactivation and avoid the limitation on $\mathrm{CH}_{4}$ yield resulting from thermodynamic equilibrium $[9,10]$. But to develop an active and stable low-temperature methanation catalyst for a slurry-bed reactor is more difficult, and now, only a few studies have been done in the laboratory $[11,12]$.

Numerous catalysts have been used for fixed-bed methanation reaction [9]. Among these catalysts, Ni-based catalysts have been widely employed due to the relatively low cost, high activity, and high selectivity to methane [13-16]. It is known that conventional Ni-based catalysts showed high catalytic activity at the high reaction temperature; however, the catalytic activity of $\mathrm{CO}$ conversion and $\mathrm{CH}_{4}$ selectivity was low at the low reaction temperature. To overcome this problem, addition of second metal such as $\mathrm{Sm}, \mathrm{Ce}$, and $\mathrm{Fe}$ has been attempted to enhance the catalytic activity and stability of Ni-based catalysts for $\mathrm{CO}$ methanation reaction, because the second metal can improve the dispersion of active metal and adjust the interaction between $\mathrm{Ni}$ and the support [17-20]. Hwang et al. [18, 19] prepared nickel-M-Al xerogel (NiMAX) catalysts doped with different second metal $(\mathrm{M}=$ $\mathrm{Fe}, \mathrm{Ni}, \mathrm{Co}, \mathrm{Ce}$, and La) by sol-gel method, and they found 
that $\mathrm{NiFeAX}$ catalyst exhibited the best catalytic performance for $\mathrm{CO}$ or $\mathrm{CO}_{2}$ methanation at low reaction temperature $\left(220^{\circ} \mathrm{C}\right.$ and $\left.230^{\circ} \mathrm{C}\right)$. Therefore, the investigations over the $\mathrm{Ni}$-Fe catalysts for the low-temperature $\mathrm{CO}$ methanation in slurry-bed would be worthwhile.

Our previous work $[21,22]$ has optimized the nickel precursor and $\mathrm{Al}_{2} \mathrm{O}_{3}$ support of $\mathrm{Ni}-\mathrm{Fe} / \mathrm{Al}_{2} \mathrm{O}_{3}$ catalysts for $\mathrm{CO}$ methanation. In this work, a series of $\mathrm{Ni}-\mathrm{Fe} / \mathrm{Al}_{2} \mathrm{O}_{3}$ catalysts with different $\mathrm{Fe}$ content were prepared by incipient wetness impregnation method and characterized by BET, XRD, UVVis DRS, $\mathrm{H}_{2}-\mathrm{TPR}, \mathrm{CO}-\mathrm{TPD}$, and XPS. The effects of Fe content on surface structure and catalytic performance of the catalysts for low-temperature CO methanation in slurry-bed reactor were studied.

\section{Experiment}

2.1. Catalyst Preparation. The commercial $\gamma-\mathrm{Al}_{2} \mathrm{O}_{3}(100-140$ mesh, supported by Shandong Alumina Company) precalcined at $550^{\circ} \mathrm{C}$ for $6 \mathrm{~h}$ was used in this study. The Ni-based catalysts were prepared by incipient wetness impregnation method, described as follows: nickel nitrate hexahydrate (Sinopharm Chemical Reagent Co., Ltd) and ferric nitrate nonahydrate (Sinopharm Chemical Reagent Co., Ltd) were dissolved in deionized water, followed by the addition of $\gamma-\mathrm{Al}_{2} \mathrm{O}_{3}$ : the slurry was continuously stirred at room temperature for $24 \mathrm{~h}$ and then dried at $120^{\circ} \mathrm{C}$ for $12 \mathrm{~h}$ and calcined at $450^{\circ} \mathrm{C}$ for $4 \mathrm{~h}$ in muffle oven; and the obtained sample was reduced at $550^{\circ} \mathrm{C}$ for $6 \mathrm{~h}$ in a flow of $25 \% \mathrm{H}_{2}$ diluted with nitrogen. The above catalysts were denoted as $16 \mathrm{Ni} x \mathrm{Fe} / \mathrm{Al}_{2} \mathrm{O}_{3}$, where 16 represents the weight percent of $\mathrm{Ni}, x$ represents the weight percent of $\mathrm{Fe}$, and $x$ is $0,1,2,4,6$, and 8 . In addition, catalyst $8 \mathrm{Fe} / \mathrm{Al}_{2} \mathrm{O}_{3}$ and commercial catalyst named J108-2Q (supported by Sichuan Shutai chemical technology Co., Ltd) were used as reference counterparts.

2.2. Characterization. X-Ray diffraction (XRD) data were obtained with Rigaku D/max 2500 diffractometer ( $\mathrm{Cu} \mathrm{K \alpha}$ radiation, $\lambda=0.154056 \mathrm{~nm}$ ) at $40 \mathrm{kV}$ and $100 \mathrm{~mA}$, and the crystallite sizes were estimated from XRD patterns applying the Scherrer equation.

The BET specific surface area, pore volume, and the average pore diameter of samples were measured by the multipoint BET analysis method using $\mathrm{N}_{2}$ adsorption isotherms at $77 \mathrm{~K}$. The measurement was performed on Micrometrics ASAP 2100 automatic device.

X-ray photoelectron spectroscopy (XPS) data were collected on Thermo Fisher ESCALAB 250Xi with Al $K \alpha$ radiation. The binding energies were calibrated by the carbon $(\mathrm{C} 1 \mathrm{~s}=284.8 \mathrm{eV})$.

Ultraviolet-visible diffuse reflectance spectra (UV-VIS DRS) were performed at room temperature in the range of 250 800 nm by a CARY 300 spectrophotometer, using MgO as the reference material.

Temperature-programmed reduction of $\mathrm{H}_{2}\left(\mathrm{H}_{2}-\mathrm{TPR}\right)$ and temperature-programmed desorption of $\mathrm{CO}$ (CO-TPD) experiments were carried out with Micrometrics Autochem II 2920 model multifunctional adsorption instrument. Prior to the TPR measurements, $20 \mathrm{mg}$ of the samples was pretreated at $350^{\circ} \mathrm{C}$ for $0.5 \mathrm{~h}$ in flowing $\mathrm{He}(50 \mathrm{~mL} / \mathrm{min})$, after cooling the reactor to room temperature, a $10 \% \mathrm{H}_{2} / 90 \% \mathrm{Ar}$ (50 $\mathrm{mL} / \mathrm{min}$ ) gas mixture was introduced, and the sample was heated to $800^{\circ} \mathrm{C}$. Prior to the TPD measurements, $40 \mathrm{mg}$ of the samples was reduced at $550^{\circ} \mathrm{C}$ and then cooled to $50^{\circ} \mathrm{C}$. $10 \% \mathrm{CO}$ diluted in $\mathrm{He}$ was passed though the sample until saturation, and the TPD profile was obtained by heating the sample from $50^{\circ} \mathrm{C}$ to $800^{\circ} \mathrm{C}$.

2.3. Catalytic Activity Evaluation. Catalytic performance evaluation was carried out in a $250 \mathrm{~mL}$ slurry-bed agitated autoclave. In each experiment, $2.0 \mathrm{~g}$ of catalyst (100-140 mesh particle) and $120 \mathrm{~mL}$ of paraffin (boiling point higher than $350^{\circ} \mathrm{C}$ ) were added into the reactor vessel and rotated at $750 \mathrm{r} / \mathrm{min} . \mathrm{N}_{2}(99.995 \%)$ was introduced into the reactor at a flow rate of $50 \mathrm{~mL} / \mathrm{min}$ to remove the air and the reactor was heated at a rate of $2^{\circ} \mathrm{C} / \mathrm{min}$ from room temperature to $280^{\circ} \mathrm{C}$. Then, the syngas of $\mathrm{H}_{2}(99.995 \%)$ and $\mathrm{CO}(99.9 \%)$ was switched as feed gas at $75 \mathrm{~mL} / \mathrm{min}$ and $25 \mathrm{~mL} / \mathrm{min}$, respectively, to synthesize methane at $1.0 \mathrm{MPa}$ with the space velocity of $3000 \mathrm{~mL} / \mathrm{g}_{\text {cat }} \cdot \mathrm{h}$. The products from the reactor were condensed by ethanol at $2^{\circ} \mathrm{C}$, the cooling liquid was removed by gas-liquid separator, and the outlet gas was quantitatively analyzed by on-line gas chromatography (Agilent 7890A), which was equipped with flame ionization detector (FID) and thermal conductivity detector (TCD), using $\mathrm{He}$ as carrier gas. FID detector equipped with $\mathrm{HP}-\mathrm{AL} / \mathrm{S}$ column $(30 \mathrm{~m} \times 530 \mu \mathrm{m} \times 15 \mu \mathrm{m})$ was used to analyze $\mathrm{C}_{1 \sim 4}$, and TCD detector equipped with Porapak-Q column $(6 \mathrm{ft} \times 1 / 8$ inch), HP-PLOT/Q column $(30 \mathrm{~m} \times 530 \mu \mathrm{m} \times 40 \mu \mathrm{m})$, and HPMOLESIEVE column $(30 \mathrm{~m} \times 530 \mu \mathrm{m} \times 25 \mu \mathrm{m})$ was used to analyze $\mathrm{CO}, \mathrm{N}_{2}$, and $\mathrm{CO}_{2}$. The temperature of FID and TCD was $300^{\circ} \mathrm{C}$ and $250^{\circ} \mathrm{C}$, respectively.

The conversion of $\mathrm{CO}$, the selectivity of $\mathrm{CH}_{4}, \mathrm{CO}_{2}$, and $\mathrm{C}_{2 \sim 4}$, and the yield of $\mathrm{CH}_{4}$ were calculated using the following expressions:

$$
\begin{gathered}
X_{\mathrm{CO}}=\frac{F\left(\mathrm{CO}_{\text {in }}\right)-F\left(\mathrm{CO}_{\text {out }}\right)}{F\left(\mathrm{CO}_{\text {in }}\right)} \times 100 \%, \\
S_{\mathrm{CH}_{4}}=\frac{F\left(\mathrm{CH}_{4, \text { out }}\right)}{F\left(\mathrm{CO}_{\text {in }}\right)-F\left(\mathrm{CO}_{\text {out }}\right)} \times 100 \%, \\
S_{\mathrm{CO}_{2}}=\frac{F\left(\mathrm{CO}_{2, \text { out }}\right)}{F\left(\mathrm{CO}_{\text {in }}\right)-F\left(\mathrm{CO}_{\text {out }}\right)} \times 100 \%, \\
S_{\mathrm{C} i}=\frac{i \times F\left(\mathrm{C}_{i, \text { out }}\right)}{F\left(\mathrm{CO}_{\text {in }}\right)-F\left(\mathrm{CO}_{\text {out }}\right)} \times 100 \% \quad(i=2,3,4), \\
Y_{\mathrm{CH}_{4}}=X_{\mathrm{CO}} \times S_{\mathrm{CH}_{4}},
\end{gathered}
$$

where $X_{\mathrm{CO}}, S_{\mathrm{CH}_{4}}, S_{\mathrm{Ci}}, S_{\mathrm{CO}_{2}}$, and $Y_{\mathrm{CH}_{4}}$ refer to the conversion of $\mathrm{CO}$; the selectivity of $\mathrm{CH}_{4}, \mathrm{C}_{2 \sim 4}$, and $\mathrm{CO}_{2}$; and the yield of $\mathrm{CH}_{4}$, respectively. $\mathrm{C}_{2 \sim 4}$ represents $\mathrm{C}_{2} \mathrm{H}_{4}, \mathrm{C}_{2} \mathrm{H}_{6}, \mathrm{C}_{3} \mathrm{H}_{6}, \mathrm{C}_{3} \mathrm{H}_{8}$, $\mathrm{C}_{4} \mathrm{H}_{8}$, and $\mathrm{C}_{4} \mathrm{H}_{10} . F$ and $W_{\text {cat }}$ represent the flow of $\mathrm{CO}, \mathrm{C}_{2 \sim 4}$, $\mathrm{CH}_{4}$, and $\mathrm{CO}_{2}(\mathrm{~mL} / \mathrm{min}, \mathrm{STP})$ and the weight of catalyst, respectively. 
TABLE 1: Catalytic performance of $16 \mathrm{NixFe} / \mathrm{Al}_{2} \mathrm{O}_{3}$ catalysts for $\mathrm{CO}$ methanation in slurry-bed reactor.

\begin{tabular}{lccccc}
\hline Catalysts & $X_{\mathrm{CO}}(\%)$ & $\mathrm{CH}_{4}$ & $\begin{array}{c}\text { Selectivity }(\%) \\
\mathrm{CO}_{2}\end{array}$ & $\mathrm{C}_{2 \sim 4}$ & $Y_{\mathrm{CH}_{4}}(\%)$ \\
\hline $16 \mathrm{Ni} / \mathrm{Al}_{2} \mathrm{O}_{3}$ & 82.5 & 87.4 & 7.8 & 4.8 & 72.1 \\
$16 \mathrm{NilFe} / \mathrm{Al}_{2} \mathrm{O}_{3}$ & 92.9 & 81.9 & 7.4 & 10.7 & 76.1 \\
$16 \mathrm{Ni} 2 \mathrm{Fe} / \mathrm{Al}_{2} \mathrm{O}_{3}$ & 96.4 & 86.7 & 7.7 & 5.6 & 83.6 \\
$16 \mathrm{Ni} 4 \mathrm{Fe} / \mathrm{Al}_{2} \mathrm{O}_{3}$ & 97.2 & 87.3 & 8.6 & 4.1 & 84.9 \\
$16 \mathrm{Ni} 6 \mathrm{Fe} / \mathrm{Al}_{2} \mathrm{O}_{3}$ & 94.8 & 84.4 & 10.8 & 4.7 & 80.0 \\
$16 \mathrm{Ni} 8 \mathrm{Fe} / \mathrm{Al}_{2} \mathrm{O}_{3}$ & 92.6 & 81.0 & 13.6 & 5.5 & 75.0 \\
$8 \mathrm{Fe} / \mathrm{Al}_{2} \mathrm{O}_{3}$ & 10.6 & 78.1 & 15.4 & 6.6 & 8.3 \\
$\mathrm{~J} 108-2 \mathrm{Q}$ & 88.9 & 82.7 & 3.4 & 13.9 & 73.5 \\
\hline
\end{tabular}

\section{Results and Discussion}

3.1. Catalytic Performance of $16 \mathrm{NixFe} / \mathrm{Al}_{2} \mathrm{O}_{3}$ Catalysts for $\mathrm{CO}$ Methanation. The catalytic performance of $16 \mathrm{Nix} F \mathrm{Fe} / \mathrm{Al}_{2} \mathrm{O}_{3}$ catalysts with different iron content for low-temperature $\mathrm{CO}$ methanation in slurry-bed reactor is listed in Table 1 . The reference catalyst $16 \mathrm{Ni} / \mathrm{Al}_{2} \mathrm{O}_{3}$ showed the conversion of $\mathrm{CO}$ and the yield of $\mathrm{CH}_{4}$ at $82.5 \%$ and $72.1 \%$, respectively, which were much higher than that of catalyst $8 \mathrm{Fe} / \mathrm{Al}_{2} \mathrm{O}_{3}$. However, the catalytic performance of the above two catalysts were lower than the commercial catalyst J108-2Q.

The introduction of iron in $16 \mathrm{NixFe} / \mathrm{Al}_{2} \mathrm{O}_{3}$ catalyst greatly improved the catalytic performance. A rise in iron content greatly enhanced CO conversion, reaching the maximum for the catalyst containing $4 \%$ iron content with outstanding conversion of $\mathrm{CO}$ and the yield of $\mathrm{CH}_{4}$ at $97.2 \%$ and $84.9 \%$, respectively. Further rise in iron content resulted in the decrease of catalytic performance. It is well known that Fe-based catalysts show high water gas shift activity, and it can be seen that the increase of iron content aggravated the water gas shifted reaction [23], resulting in the more production of $\mathrm{CO}_{2}$. In addition, the selectivity of $\mathrm{C}_{2 \sim 4}$ changed slightly with the increase of iron content except the catalyst with $1 \%$ iron content.

3.2. BET. Textural properties of $\gamma-\mathrm{Al}_{2} \mathrm{O}_{3}$ support and $16 \mathrm{Ni} x \mathrm{Fe} / \mathrm{Al}_{2} \mathrm{O}_{3}(x=0,1,4,8)$ catalysts are summarized in Table 2. The $\gamma-\mathrm{Al}_{2} \mathrm{O}_{3}$ support got a high BET surface area of $191 \mathrm{~m}^{2} / \mathrm{g}$, and the pore volume and the average pore diameter were $0.38 \mathrm{~cm}^{3} / \mathrm{g}$ and $5.81 \mathrm{~nm}$, respectively. After the loading of $16 \% \mathrm{Ni}$, part of nickel species began to aggregate and formed crystalline nickel oxide clusters, which may block the pores of $\gamma-\mathrm{Al}_{2} \mathrm{O}_{3}$ and thus make the BET surface area of catalyst $16 \mathrm{Ni} / \mathrm{Al}_{2} \mathrm{O}_{3}$ decreases to $148 \mathrm{~m}^{2} / \mathrm{g}[4,24]$; in addition, both the pore volume and average pore diameter of catalyst $16 \mathrm{Ni} / \mathrm{Al}_{2} \mathrm{O}_{3}$ decreased. However, the catalysts $16 \mathrm{Ni} x \mathrm{Fe} / \mathrm{Al}_{2} \mathrm{O}_{3}$ $(x=1,4,8)$ modified with iron showed a slightly higher BET surface area compared with $16 \mathrm{Ni} / \mathrm{Al}_{2} \mathrm{O}_{3}$ catalyst, implying that the addition of iron improved the dispersion of $\mathrm{Ni}$ species and decreased the agglomeration; similar results were also reported in other literatures $[4,24,25]$.

3.3. XRD. Figure 1(a) shows the XRD patterns of calcined catalysts $16 \mathrm{Ni} x \mathrm{Fe} / \mathrm{Al}_{2} \mathrm{O}_{3}$. The diffraction peaks of $\gamma-\mathrm{Al}_{2} \mathrm{O}_{3}$
TABLE 2: Textural properties of $\gamma-\mathrm{Al}_{2} \mathrm{O}_{3}$ support and $16 \mathrm{Ni} x \mathrm{Fe} / \mathrm{Al}_{2} \mathrm{O}_{3}$ catalysts.

\begin{tabular}{lccc}
\hline Sample & $\begin{array}{c}\text { BET surface } \\
\text { area }\left(\mathrm{m}^{2} / \mathrm{g}\right)\end{array}$ & $\begin{array}{c}\text { Pore volume } \\
\left(\mathrm{cm}^{3} / \mathrm{g}\right)\end{array}$ & $\begin{array}{c}\text { Average pore } \\
\text { diameter }(\mathrm{nm})\end{array}$ \\
\hline$\gamma-\mathrm{Al}_{2} \mathrm{O}_{3}$ & 192 & 0.38 & 5.81 \\
$16 \mathrm{Ni} / \mathrm{Al}_{2} \mathrm{O}_{3}$ & 148 & 0.28 & 5.50 \\
$16 \mathrm{NilFe} / \mathrm{Al}_{2} \mathrm{O}_{3}$ & 153 & 0.28 & 5.42 \\
$16 \mathrm{Ni} 4 \mathrm{Fe} / \mathrm{Al}_{2} \mathrm{O}_{3}$ & 158 & 0.27 & 5.31 \\
$16 \mathrm{Ni} 8 \mathrm{Fe} / \mathrm{Al}_{2} \mathrm{O}_{3}$ & 151 & 0.27 & 5.24 \\
\hline
\end{tabular}

were presented at $2 \theta$ angle of $37.4^{\circ}, 45.8^{\circ}$, and $66.9^{\circ}$, and characteristic diffraction peaks due to $\mathrm{NiO}$ were observed at $2 \theta$ of $37.4^{\circ}, 43.6^{\circ}$, and $63.1^{\circ}$, and no diffraction peaks of nickel nitrate hexahydrate were observed, indicating that $\mathrm{Ni}$ species in $16 \mathrm{Ni} x \mathrm{Fe} / \mathrm{Al}_{2} \mathrm{O}_{3}$ catalyst were mainly presented as $\mathrm{NiO}$. It is interesting to note that the characteristic peaks of $\mathrm{NiO}$ gradually decreased with the increase of iron content. In addition, no diffraction peaks of iron species were observed in XRD patterns even if the content of iron reached $8 \%$.

Figure 1(b) displays the XRD patterns of reduced catalysts $16 \mathrm{Ni} x \mathrm{Fe} / \mathrm{Al}_{2} \mathrm{O}_{3}$. It can be seen that all the reduced catalysts exhibited the characteristic peaks of $\mathrm{Ni}$ at $2 \theta$ angle of $44.3^{\circ}$, $51.8^{\circ}$ and $76.0^{\circ}$, indicating that $\mathrm{NiO}$ was reduced to metallic Ni. The diffraction peaks due to iron species were not detected. It is noted that, compared with reference catalyst $16 \mathrm{Ni} / \mathrm{Al}_{2} \mathrm{O}_{3}$, the diffraction peak of catalysts $16 \mathrm{Ni} x \mathrm{Fe} / \mathrm{Al}_{2} \mathrm{O}_{3}$ $(x \geq 2)$ exhibited lower angles by increasing the iron content; although this change was not obvious, it is an effect of a significant interaction between iron and $\mathrm{Ni}$, and the reason was due to the formation of Ni-Fe alloy, which appeared at $44.3^{\circ}, 51.5^{\circ}$, and $75.9^{\circ}[20,26]$, and the intensity of metal $\mathrm{Ni}$ decreased, indicating that the crystallite size of Ni decreased. Combined with the catalytic performance listed in Table 1, the results suggested that the formation of $\mathrm{Ni}-\mathrm{Fe}$ alloy must be an important factor for $\mathrm{CO}$ methanation reaction over the $\mathrm{Ni}$ species that existed in the catalysts.

3.4. UV-Vis DRS. Figure 2 depicts the UV-Vis DRS of calcined $16 \mathrm{Ni} x \mathrm{Fe} / \mathrm{Al}_{2} \mathrm{O}_{3}$ catalysts. The absorption band position was determined by the first-derivative of absorption bands [27]. It can be seen that all catalysts showed the absorption bands (optical absorption threshold) in the range of 300 


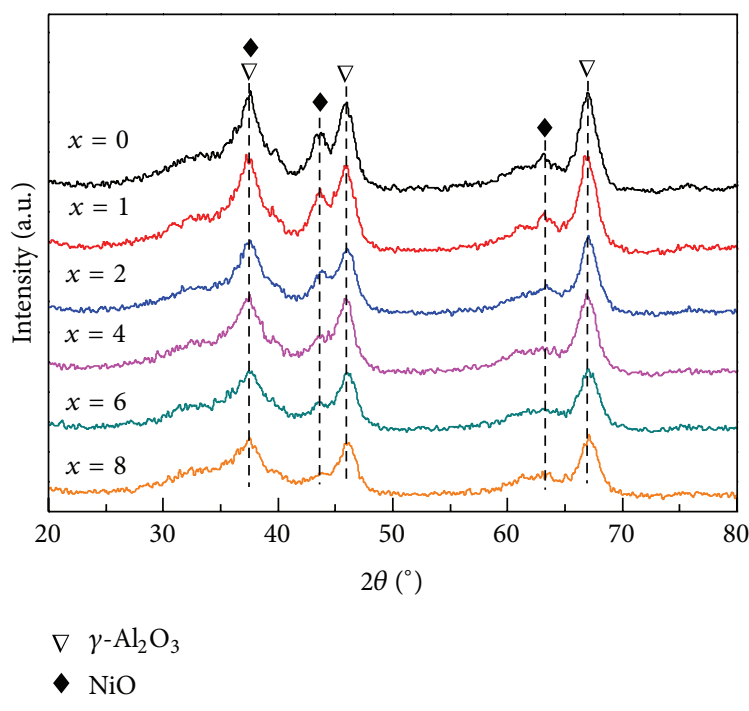

(a)

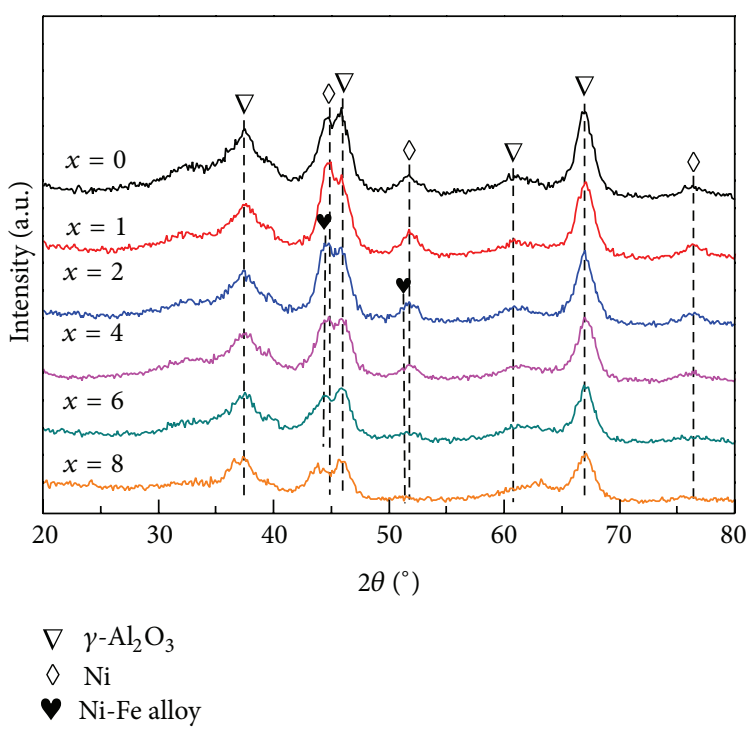

(b)

FIGURE 1: XRD patterns of catalysts $16 \mathrm{Ni} x \mathrm{Fe} / \mathrm{Al}_{2} \mathrm{O}_{3}$ : (a) calcined and (b) reduced.

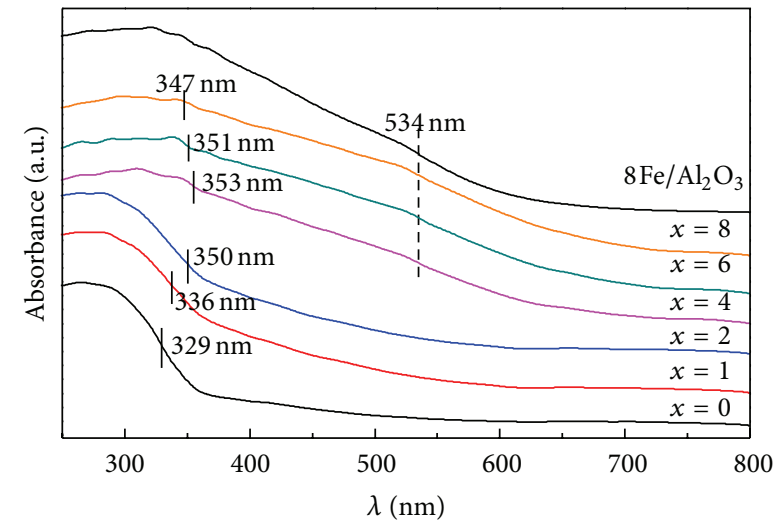

FIGURE 2: UV-Vis DRS of calcined catalysts $16 \mathrm{Ni} x \mathrm{Fe} / \mathrm{Al}_{2} \mathrm{O}_{3}$.

$600 \mathrm{~nm}$. Compared with catalyst $16 \mathrm{Ni} / \mathrm{Al}_{2} \mathrm{O}_{3}(329 \mathrm{~nm})$, the absorption bands of $16 \mathrm{Ni} x \mathrm{Fe} / \mathrm{Al}_{2} \mathrm{O}_{3}$ catalysts in the spectra were all red-shifted with the increase of iron content, and the maximum absorption band at $353 \mathrm{~nm}$ was found on catalyst $16 \mathrm{Ni} 4 \mathrm{Fe} / \mathrm{Al}_{2} \mathrm{O}_{3}$, indicating that there was a strongly interaction between $\mathrm{Ni}$ species and iron species [28]. While for the catalyst $8 \mathrm{Fe} / \mathrm{Al}_{2} \mathrm{O}_{3}$, the absorption band was exhibited at $534 \mathrm{~nm}$, which can be ascribed to the existence of $\mathrm{Fe}_{2} \mathrm{O}_{3}$ species [29]. Catalysts $16 \mathrm{Ni} x \mathrm{Fe} / \mathrm{Al}_{2} \mathrm{O}_{3}$ with the iron content above $4 \%$ also exhibited the same absorption band position at $534 \mathrm{~nm}$, except for the absorption band in the range of $300 \sim 400 \mathrm{~nm}$. The results indicated that part of iron existed as $\mathrm{Fe}_{2} \mathrm{O}_{3}$, although it was not detected by XRD patterns in Figure 1(a).

3.5. $\mathrm{H}_{2}-\mathrm{TPR}$. The $\mathrm{H}_{2}$-TPR profiles of $16 \mathrm{Ni} x \mathrm{Fe} / \mathrm{Al}_{2} \mathrm{O}_{3}$ catalysts are shown in Figure 3. For comparison, the TPR profile of catalyst $8 \mathrm{Fe} / \mathrm{Al}_{2} \mathrm{O}_{3}$ is also presented in Figure 3. The

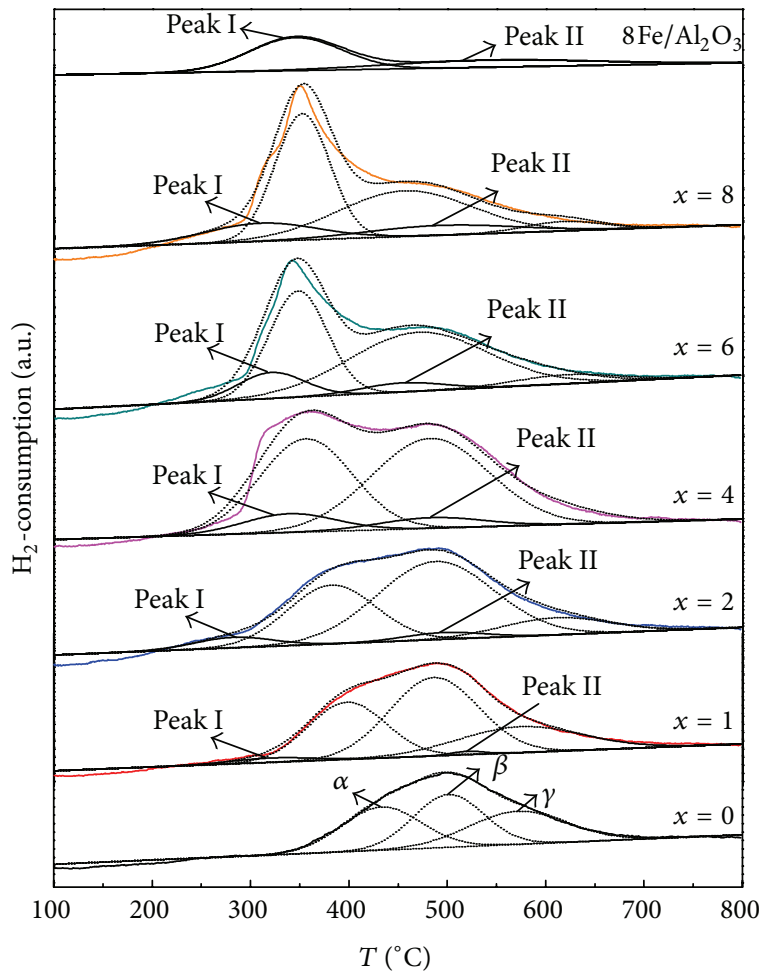

FIGURE 3: $\mathrm{H}_{2}$-TPR profiles of catalysts $16 \mathrm{Ni} x \mathrm{Fe} / \mathrm{Al}_{2} \mathrm{O}_{3}$.

reducible $\mathrm{NiO}$ species over the $\mathrm{Al}_{2} \mathrm{O}_{3}$ support are classified into three types: $\alpha, \beta$, and $\gamma[15,30]$. The overlapped peaks in the temperature range of $200 \sim 440^{\circ} \mathrm{C}$ were ascribed to the reduction peak of $\mathrm{Fe}_{2} \mathrm{O}_{3} \rightarrow \mathrm{Fe}_{3} \mathrm{O}_{4}$ (peak I) and the reduction of $\alpha-\mathrm{NiO}$, which weakly interacted with or kept away from $\mathrm{Al}_{2} \mathrm{O}_{3}$ support; the peaks in the range of $440 \sim$ $600^{\circ} \mathrm{C}$ were assigned to the reduction peak of $\mathrm{Fe}_{3} \mathrm{O}_{4} \rightarrow \mathrm{Fe}$ 


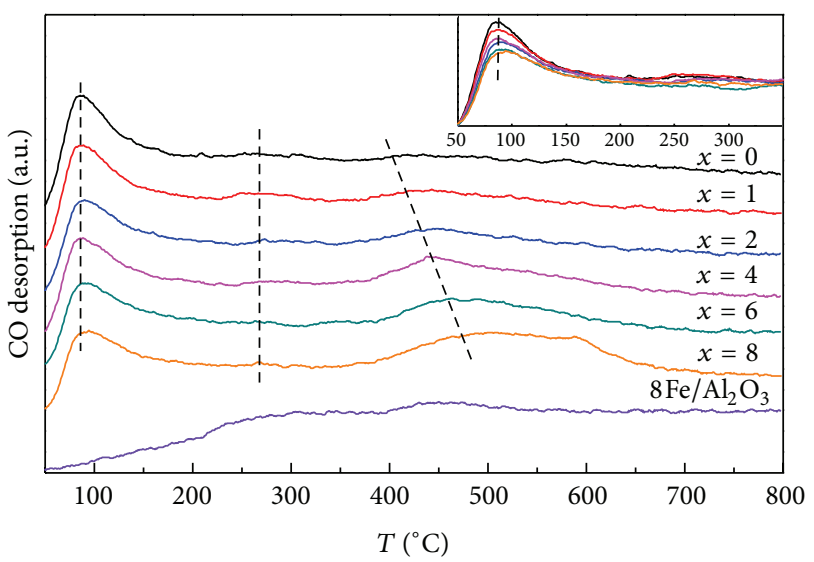

FIGURE 4: CO-TPD profiles of the reduced catalysts $16 \mathrm{Ni} x \mathrm{Fe} / \mathrm{Al}_{2} \mathrm{O}_{3}$.

(peak II) and the reduction peak of $\beta-\mathrm{NiO}$, which had a strong interaction state with the support; additionally, the reduction peak in the range of $550 \sim 750^{\circ} \mathrm{C}$ was mainly attributed to the reduction of $\mathrm{NiAl}_{2} \mathrm{O}_{4}$ spinel $[31,32]$.

After the introduction of iron, the reduction peaks of $16 \mathrm{Ni} x \mathrm{Fe} / \mathrm{Al}_{2} \mathrm{O}_{3}$ shifted to lower temperature, and the total reduction peak areas increased gradually with the increase of iron content, indicating that the addition of iron facilitated the reduction of catalysts. It is believed that the addition of iron weakened the interaction between $\mathrm{Ni}$ and $\mathrm{Al}_{2} \mathrm{O}_{3}$ support, changed the microchemical environment of $\mathrm{Ni}$ and iron species on the surface of the catalyst, and thus increased the amount of reduction species [33-35].

In order to clarify the effect of iron content on the reduction of Ni species, Gaussian fitting analysis was conducted, and the reduction peak area of Ni species was obtained by subtracting the reduction peak area of corresponding Fe content from the total hydrogen consumption of each catalyst; the results are shown in Figure 3 and Table 3. According to the iron content of $16 \mathrm{Ni} x \mathrm{Fe} / \mathrm{Al}_{2} \mathrm{O}_{3}$ catalysts and taking the hydrogen consumption of $8 \mathrm{Fe} / \mathrm{Al}_{2} \mathrm{O}_{3}$ catalyst as a benchmark, it can be seen that the total hydrogen consumption increased with the increase of iron content, which was due to the reduction of $\mathrm{Fe}$ species and the $\mathrm{Ni}$ species. Catalyst $16 \mathrm{Ni} / \mathrm{Al}_{2} \mathrm{O}_{3}$ got the smallest amount of $\alpha$ reduction peak, and the amount of $\alpha$ peak increased gradually with the increase of iron content, while the amount of $\gamma$ reduction peak decreased, indicating that the increase of iron content improved the reduction species of $\mathrm{NiO}$. Among the catalysts examined, when the iron content reached $4 \%$, the amount of $\beta$ reduction peak reached the maximum (45.3\%); further increase of iron content resulted in the decrease of $\beta$ peak amount. The results were consistent with the catalytic performance of catalysts $16 \mathrm{Ni} x \mathrm{Fe} / \mathrm{Al}_{2} \mathrm{O}_{3}$; thus, it can be concluded that the $\beta-\mathrm{NiO}$ species was the main reason for enhancing the catalytic activities of CO methanation. Similar results have been reported in $\mathrm{Hu}$ et al.s study [15]. In addition, it can be seen that the reduction peak area of peak I of catalyst $8 \mathrm{Fe} / \mathrm{Al}_{2} \mathrm{O}_{3}$ was larger than peak II, and the shape of peak I was sharp, while peak II was broad, indicating that the reduction degree of $\mathrm{Fe}_{2} \mathrm{O}_{3}$ to $\mathrm{Fe}_{3} \mathrm{O}_{4}$ was high and the reduction rate was fast, while the reduction

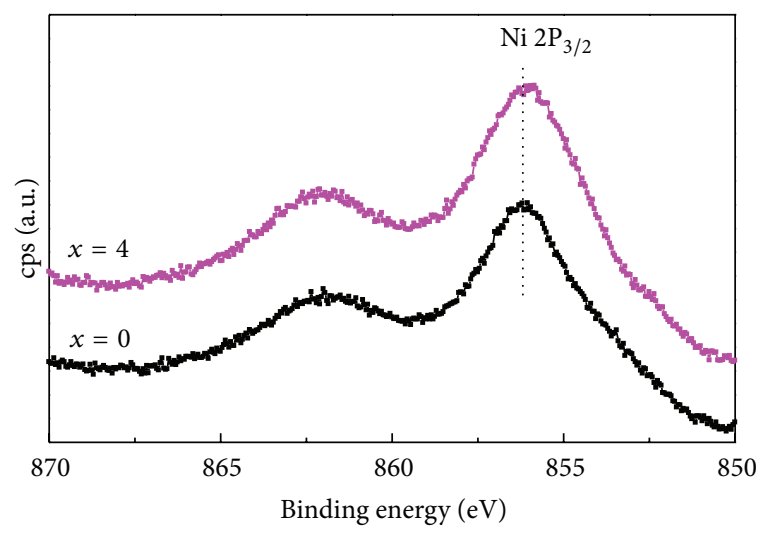

FIGURE 5: XPS spectra of the reduced catalysts $16 \mathrm{Ni} x \mathrm{Fe} / \mathrm{Al}_{2} \mathrm{O}_{3}$.

degree of $\mathrm{Fe}_{3} \mathrm{O}_{4}$ to $\mathrm{Fe}$ was low and the reduction rate was slow. With the increase of $\mathrm{Fe}$ content, the relative reduction content of $\mathrm{Fe}_{2} \mathrm{O}_{3}$ to $\mathrm{Fe}_{3} \mathrm{O}_{4}$ increased from $2.3 \%$ to $11.9 \%$.

It is reported that $\mathrm{Fe}_{3} \mathrm{O}_{4}$ species was the main active component of water gas shift reaction [23], indicating that the catalyst with larger content of $\mathrm{Fe}_{3} \mathrm{O}_{4}$ favored more $\mathrm{CO}_{2}$ production, and the results were in agreement with the catalytic performance listed in Table 1.

3.6. CO-TPD. Figure 4 shows the CO-TPD profiles of $16 \mathrm{Ni} x \mathrm{Fe} / \mathrm{Al}_{2} \mathrm{O}_{3}$ catalysts. All the catalysts exhibited a lowtemperature peak centered at $\sim 85^{\circ} \mathrm{C}$, which was attributed to the desorption of weak chemisorption or physical adsorption of $\mathrm{CO}$. The weak peaks centered at around $265^{\circ} \mathrm{C}$ could be due to desorption of the middle intensive $\mathrm{CO}$ adsorption, and the highest desorption temperature shoulder spanning from 400 to $\sim 500^{\circ} \mathrm{C}$ was probably attributed to the strong adsorption of $\mathrm{CO}$ [36]. It also can be seen that catalyst $8 \mathrm{Fe} / \mathrm{Al}_{2} \mathrm{O}_{3}$ exhibited almost no desorption peaks, which means that the adsorption of $\mathrm{CO}$ of catalysts $16 \mathrm{Ni} x \mathrm{Fe} / \mathrm{Al}_{2} \mathrm{O}_{3}$ was mostly attributed to the active component $\mathrm{Ni}$ and that the increase of $\mathrm{CO}$ adsorption amount was attributed to the increase of Fe content and the interaction between $\mathrm{Fe}$ and Ni. The former results of $\mathrm{XRD}, \mathrm{BET}$, and $\mathrm{H}_{2}$-TPR showed that the introduction of $\mathrm{Fe}$ improved the dispersion of $\mathrm{Ni}$ and increased the BET specific surface area and the amount of active component $\mathrm{Ni}$ which facilitated the adsorption of more CO.

3.7. XPS. Figure 5 shows the Ni $2 p_{3 / 2}$ core level spectra of reduced catalysts $16 \mathrm{Ni} / \mathrm{Al}_{2} \mathrm{O}_{3}$ and $16 \mathrm{Ni} 4 \mathrm{Fe} / \mathrm{Al}_{2} \mathrm{O}_{3}$. The binding energies of $\mathrm{Ni} 2 \mathrm{p}_{3 / 2}$ for $16 \mathrm{Ni} / \mathrm{Al}_{2} \mathrm{O}_{3}$ and $16 \mathrm{Ni} 4 \mathrm{Fe} / \mathrm{Al}_{2} \mathrm{O}_{3}$ were $856.1 \mathrm{eV}$ and $855.9 \mathrm{eV}$, respectively, which were higher than that pure $\mathrm{NiO}(854.4 \mathrm{eV})$ and $\mathrm{NiAl}_{2} \mathrm{O}_{4}(856.2 \mathrm{eV})$ [37], indicating that there might be two kinds of $\mathrm{Ni}$ species $(\mathrm{NiO}$ and $\mathrm{NiAl}_{2} \mathrm{O}_{4}$ ) on the surface of catalysts. The large amount of $\mathrm{NiO}$ could be formed by reoxidation of metallic Ni through contacting oxygen in air during the XPS experiments [38]. It could be noted that the binding energy of the $\mathrm{Ni} 2 \mathrm{p}_{3 / 2}$ peak of $16 \mathrm{Ni} / \mathrm{Al}_{2} \mathrm{O}_{3}$ sample was slightly higher than that of $16 \mathrm{Ni} 4 \mathrm{Fe} / \mathrm{Al}_{2} \mathrm{O}_{3}$, which could be attributed to the stronger interaction between $\mathrm{Ni}$ and support in $16 \mathrm{Ni} / \mathrm{Al}_{2} \mathrm{O}_{3}$ [39]. 
TABLE 3: Gaussian fitting analysis of $\mathrm{H}_{2}$-TPR patterns of $16 \mathrm{NixFe} / \mathrm{Al}_{2} \mathrm{O}_{3}$ catalysts.

\begin{tabular}{|c|c|c|c|c|c|c|c|c|}
\hline \multirow{2}{*}{ Catalyst } & \multicolumn{3}{|c|}{$\mathrm{H}_{2}$-consumption $(\mathrm{mmol} / \mathrm{g})$} & \multicolumn{5}{|c|}{ Reduction temperature $\left({ }^{\circ} \mathrm{C}\right) /$ relative content $(\%)$} \\
\hline & Total & Reduced Fe $\mathrm{a}^{\mathrm{a}}$ & Reduced Ni & $\alpha$ & $\beta$ & $\gamma$ & Peak I & Peak II \\
\hline $16 \mathrm{Ni} / \mathrm{Al}_{2} \mathrm{O}_{3}$ & 2.04 & - & 2.04 & $432.4 / 33.0$ & $500.5 / 35.8$ & $570.9 / 31.2$ & - & - \\
\hline $16 \mathrm{NilFe} / \mathrm{Al}_{2} \mathrm{O}_{3}$ & 2.13 & 0.06 & 2.07 & $396.9 / 34.4$ & $485.3 / 39.6$ & $573.4 / 23.0$ & $321.1 / 2.3$ & $520.1 / 0.7$ \\
\hline $16 \mathrm{Ni} 2 \mathrm{Fe} / \mathrm{Al}_{2} \mathrm{O}_{3}$ & 2.36 & 0.25 & 2.11 & $381.3 / 36.5$ & $486.8 / 41.7$ & $609.0 / 12.5$ & $281.3 / 6.2$ & $496.0 / 3.1$ \\
\hline $16 \mathrm{Ni} 4 \mathrm{Fe} / \mathrm{Al}_{2} \mathrm{O}_{3}$ & 2.52 & 0.36 & 2.16 & $355.3 / 37.4$ & $481.5 / 45.3$ & 601.0/7.4 & $339.2 / 6.3$ & $483.5 / 3.5$ \\
\hline $16 \mathrm{Ni} 6 \mathrm{Fe} / \mathrm{Al}_{2} \mathrm{O}_{3}$ & 2.59 & 0.47 & 2.12 & $347.4 / 38.6$ & $460.6 / 38.7$ & $591.4 / 6.7$ & $312.0 / 10.9$ & $454.2 / 5.2$ \\
\hline $16 \mathrm{Ni} 8 \mathrm{Fe} / \mathrm{Al}_{2} \mathrm{O}_{3}$ & 2.80 & 0.56 & 2.24 & $351.6 / 40.2$ & $455.5 / 35.3$ & $617.5 / 4.2$ & $310.2 / 11.9$ & $492.7 / 8.4$ \\
\hline $8 \mathrm{Fe} / \mathrm{Al}_{2} \mathrm{O}_{3}$ & 0.56 & 0.56 & - & - & - & - & $349.9 / 66.3$ & $521.8 / 33.7$ \\
\hline
\end{tabular}

${ }^{\mathrm{a}}$ The value calculated by different $\mathrm{Fe}$ content based on the $\mathrm{H}_{2}$-consumpution of $8 \mathrm{Fe} / \mathrm{Al}_{2} \mathrm{O}_{3}$ catalyst.

As expected, catalyst $16 \mathrm{Ni} 4 \mathrm{Fe} / \mathrm{Al}_{2} \mathrm{O}_{3}$ possessed slightly higher $\mathrm{Ni} / \mathrm{Al}$ atomic ratio (0.085) than that of $16 \mathrm{Ni} / \mathrm{Al}_{2} \mathrm{O}_{3}$ (0.082), indicating that the introduction of $\mathrm{Fe}$ improved the dispersion of $\mathrm{Ni}$ species on the surface of catalyst $16 \mathrm{Ni} 4 \mathrm{Fe} / \mathrm{Al}_{2} \mathrm{O}_{3}$, which was in accordance with the results of $\mathrm{XRD}, \mathrm{H}_{2}-\mathrm{TPR}$, and BET.

\section{Conclusions}

The catalytic performance of catalyst $16 \mathrm{Ni} x \mathrm{Fe} / \mathrm{Al}_{2} \mathrm{O}_{3}$ for $\mathrm{CO}$ methanation in slurry-bed reactor was greatly influenced by the content of iron. The introduction of iron improved the dispersion of $\mathrm{Ni}$ species and decreased the reduction temperature, and Ni-Fe alloy was formed when the content of iron exceeded $2 \%$, which was favorable for the methanation of CO. With the increase of iron content, the catalytic performance of CO methanation increased at first and then decreased. Excessive iron content covered the active component $\mathrm{Ni}$ and aggravated the water gas shift reaction.

\section{Conflict of Interests}

The authors declare that they have no conflict of interests regarding the publication of this paper.

\section{Acknowledgments}

This work was supported by the National Basic Research Program of China (973 Program, no. 2012CB723105), Youth Foundation of Shanxi Province (no. 2013021007-4), China Postdoctoral Science Foundation (no. 2013M541210), and Youth Foundation of Taiyuan University of Technology (no. 2012L040). The authors gratefully appreciate the help from Li Congming (Japan Gas Synthesis CO. LTD) for the grammar and technical check.

\section{References}

[1] J. Kopyscinski, T. J. Schildhauer, and S. M. A. Biollaz, "Production of synthetic natural gas (SNG) from coal and dry biomassa technology review from 1950 to 2009," Fuel, vol. 89, no. 8, pp. 1763-1783, 2010.

[2] J. Zhang, N. Fatah, S. Capela, Y. Kara, O. Guerrini, and A. Y. Khodakov, "Kinetic investigation of carbon monoxide hydrogenation under realistic conditions of methanation of biomass derived syngas," Fuel, vol. 111, pp. 845-854, 2013.

[3] G. Q. Zhang, T. J. Sun, J. X. Peng, S. Wang, and S. D. Wang, "A comparison of $\mathrm{Ni} / \mathrm{SiC}$ and $\mathrm{Ni} / \mathrm{Al}_{2} \mathrm{O}_{3}$ catalyzed total methanation for production of synthetic natural gas," Applied Catalysis A: General, vol. 462-463, pp. 75-81, 2013.

[4] A. M. Zhao, W. Y. Ying, H. T. Zhang, H. F. Ma, and D. Y. Fang, "Ni/ $\mathrm{Al}_{2} \mathrm{O}_{3}$ catalysts for syngas methanation: effect of $\mathrm{Mn}$ promoter," Journal of Natural Gas Chemistry, vol. 21, no. 2, pp. 170-177, 2012.

[5] M. C. Seemann, T. J. Schildhauer, and S. M. A. Biollaz, "Fluidized bed methanation of wood-derived producer gas for the production of synthetic natural gas," Industrial and Engineering Chemistry Research, vol. 49, no. 15, pp. 7034-7038, 2010.

[6] J. Li, L. Zhou, P. C. Li et al., "Enhanced fluidized bed methanation over a $\mathrm{Ni} / \mathrm{Al}_{2} \mathrm{O}_{3}$ catalyst for production of synthetic natural gas," Chemical Engineering Journal, vol. 219, pp. 183-189, 2013.

[7] B. Liu and S. F. Ji, "Comparative study of fluidized-bed and fixed-bed reactor for syngas methanation over $\mathrm{Ni}-\mathrm{W} / \mathrm{TiO}_{2}-\mathrm{SiO}_{2}$ catalyst," Journal of Energy Chemistry, vol. 22, no. 5, pp. 740-746, 2013.

[8] S. B. Alpert, M. B. Sherwin, and N. P. Cochran, "Slurry phase methanation process," US Patent 3989734, 1976.

[9] Z. He, X. X. Cui, H. Fan, Y. Chang, and Z. Li, "Research of coal-to-synthetic natural gas technology and catalyst," Chemical Industry and Engineering Progress, vol. 30, no. S1, pp. 388-392, 2011.

[10] Q. G. Zhang, Z. Li, S. W. Yan et al., "Process for synthesizing natural gas by methanation of coal synthesis gas," CN Patent 101979476, 2011.

[11] L. He, Y. G. Wang, W. B. Gong, F. F. Yang, D. P. Xu, and H. Y. Zhang, "Research of the catalysts for methanation in slurry bed reactor," Chemical Industry and Engineering Progress, vol. 31, no. S1, pp. 311-314, 2012.

[12] J. F. Zhang, Y. X. Bai, Q. D. Zhang, H. J. Xie, Y. S. Tan, and Y. Z. Han, "Low temperature methanation of syngas in a slurry reactor over $\mathrm{Zr}$-doped $\mathrm{Ni} / \gamma-\mathrm{Al}_{2} \mathrm{O}_{3}$ catalyst," Journal of Fuel Chemistry and Technology, vol. 41, no. 8, pp. 966-971, 2013.

[13] T. Bligaard, J. K. Nørskov, S. Dahl, J. Matthiesen, C. H. Christensen, and J. Sehested, "The Brønsted-Evans-Polanyi relation and the volcano curve in heterogeneous catalysis," Journal of Catalysis, vol. 224, no. 1, pp. 206-217, 2004.

[14] S. Hwang, J. Lee, U. G. Hong et al., "Methane production from carbon monoxide and hydrogen over nickel-alumina xerogel catalyst: effect of nickel content," Journal of Industrial and Engineering Chemistry, vol. 17, no. 1, pp. 154-157, 2011. 
[15] D. C. Hu, J. J. Gao, Y. Ping et al., "Enhanced investigation of $\mathrm{CO}$ methanation over $\mathrm{Ni} / \mathrm{Al}_{2} \mathrm{O}_{3}$ catalysts for synthetic natural gas production," Industrial and Engineering Chemistry Research, vol. 51, no. 13, pp. 4875-4886, 2012.

[16] X. L. Yan, Y. Liu, B. R. Zhao, Z. Wang, Y. Wang, and C. J. Liu, "Methanation over $\mathrm{Ni} / \mathrm{SiO}_{2}$ : effect of the catalyst preparation methodologies," International Journal of Hydrogen Energy, vol. 38, no. 5, pp. 2283-2291, 2013.

[17] A. L. Kustov, A. M. Frey, K. E. Larsen, T. Johannessen, J. K. Nørskov, and C. H. Christensen, "CO methanation over supported bimetallic $\mathrm{Ni}-\mathrm{Fe}$ catalysts: from computational studies towards catalyst optimization," Applied Catalysis A: General, vol. 320, pp. 98-104, 2007.

[18] S. Hwang, U. G. Hong, J. Lee et al., "Methanation of carbon dioxide over mesoporous Nickel-M-Alumina ( $\mathrm{M}=\mathrm{Fe}, \mathrm{Zr}, \mathrm{Ni}$, Y, and $\mathrm{Mg}$ ) xerogel catalysts: effect of second metal," Catalysis Letters, vol. 142, no. 7, pp. 860-868, 2012.

[19] S. Hwang, J. Lee, U. G. Hong et al., "Hydrogenation of carbon monoxide to methane over mesoporous nickel-M-alumina $(\mathrm{M}=\mathrm{Fe}, \mathrm{Ni}, \mathrm{Co}, \mathrm{Ce}$, and $\mathrm{La})$ xerogel catalysts," Journal of Industrial and Engineering Chemistry, vol. 18, no. 1, pp. 243-248, 2012.

[20] D. Y. Tian, Z. H. Liu, D. D. Li, H. L. Shi, W. X. Pan, and Y. Cheng, "Bimetallic Ni-Fe total-methanation catalyst for the production of substitute natural gas under high pressure," Fuel, vol. 104, pp. 224-229, 2013.

[21] P. Z. Zhong, F. H. Meng, X. X. Cui, J. Liu, and Z. Li, "Catalytic performance of $\mathrm{Ni}-\mathrm{Fe} / \gamma-\mathrm{Al}_{2} \mathrm{O}_{3}$ catalyst prepared from different nickel precursors for CO methanation," Chemical Industry and Engineering Progress, vol. 32, no. 8, pp. 1845-1848, 2013.

[22] J. Liu, F. H. Meng, P. Z. Zhong, K. M. Ji, and Z. Li, "Effect of support texture properties on $\mathrm{Ni}-\mathrm{Fe} / \gamma-\mathrm{Al}_{2} \mathrm{O}_{3}$ catalyst structure and catalytic performance for $\mathrm{CO}$ methanation," Natural Gas Chemical Industry, vol. 38, no. 4, pp. 6-10, 2013.

[23] C. Rhodes, G. J. Hutchings, and A. M. Ward, "Water-gas shift reaction: finding the mechanistic boundary," Catalysis Today, vol. 23, no. 1, pp. 43-58, 1995.

[24] K. Y. Koo, H.-S. Roh, U. H. Jung, and W. L. Yoon, "Combined $\mathrm{H}_{2} \mathrm{O}$ and $\mathrm{CO}_{2}$ reforming of $\mathrm{CH}_{4}$ over Ce-promoted $\mathrm{Ni} / \mathrm{Al}_{2} \mathrm{O}_{3}$ catalyst for gas to liquid (GTL) process: enhancement of Ni$\mathrm{CeO}_{2}$ interaction," Catalysis Today, vol. 185, no. 1, pp. 126-130, 2012.

[25] A. Iriondo, V. L. Barrio, J. F. Cambra et al., "Hydrogen production from glycerol over nickel catalysts supported on $\mathrm{Al}_{2} \mathrm{O}_{3}$ modified by Mg, Zr, Ce or La," Topics in Catalysis, vol. 49, no. 1-2, pp. 46-58, 2008.

[26] H. Wang, Y. Z. Fang, Y. Liu, and X. Bai, "Perovskite $\mathrm{LaFeO}_{3}$ supported bi-metal catalyst for syngas methanation," Journal of Natural Gas Chemistry, vol. 21, no. 6, pp. 745-752, 2012.

[27] F. Y. Sun, M. Wu, W. Z. Li, X. Y. Li, W. Z. Gu, and F. D. Wang, "Relationship between crystallite size and photocatalytic activity of titanium dioxide," Chinese Journal of Catalysis, vol. 19, no. 3, pp. 229-233, 1998.

[28] B. Tang, Q. Jiang, X. W. He, and H. X. Shen, "Study on the surface diffuse reflectance ultraviolet-visible spectra of the multicomponent metal catalysts," Spectroscopy and Spectral Analysis, vol. 19, no. 1, pp. 100-101, 1999.

[29] N. Malengreau, J.-P. Muller, and G. Calas, "Fe-speciation in kaolins: a diffuse reflectance study," Clays \& Clay Minerals, vol. 42, no. 2, pp. 137-147, 1994.

[30] X. Hu, L. J. Zhang, and G. X. Lu, "Pruning of the surface species on $\mathrm{Ni} / \mathrm{Al}_{2} \mathrm{O}_{3}$ catalyst to selective production of hydrogen via acetone and acetic acid steam reforming," Applied Catalysis A: General, vol. 427-428, pp. 49-57, 2012.

[31] R. Da Paz Fiuza, M. Aurélio Da Silva, and J. S. Boaventura, "Development of Fe-Ni/YSZ-GDC electrocatalysts for application as SOFC anodes: XRD and TPR characterization and evaluation in the ethanol steam reforming reaction," International Journal of Hydrogen Energy, vol. 35, no. 20, pp. 11216-11228, 2010.

[32] S.-H. Kang, J.-H. Ryu, J.-H. Kim et al., "Co-methanation of CO and $\mathrm{CO}_{2}$ on the $\mathrm{Ni}_{X}-\mathrm{Fe}_{1-X} / \mathrm{Al}_{2} \mathrm{O}_{3}$ catalysts; effect of Fe contents," Korean Journal of Chemical Engineering, vol. 28, no. 12, pp. 2282-2286, 2011.

[33] W.-J. Wang and Y.-W. Chen, "Influence of metal loading on the reducibility and hydrogenation activity of cobalt/alumina catalysts," Applied Catalysis, vol. 77, no. 2, pp. 223-233, 1991.

[34] J. Sehested, K. E. Larsen, A. L. Kustov et al., "Discovery of technical methanation catalysts based on computational screening," Topics in Catalysis, vol. 45, no. 1-4, pp. 9-13, 2007.

[35] N. Wang, Z. J. Sun, Y. Z. Wang, X. Q. Gao, and Y. X. Zhao, "Preparation of bimetallic Ni-Fe/ $\gamma-\mathrm{Al}_{2} \mathrm{O}_{3}$ catalyst and its activity for CO methanation," Journal of Fuel Chemistry and Technology, vol. 39, no. 3, pp. 219-223, 2011.

[36] Q. H. Liu, L. W. Liao, Z. L. Liu, and X. F. Dong, "Effect of $\mathrm{ZrO}_{2}$ crystalline phase on the performance of $\mathrm{Ni}-\mathrm{B} / \mathrm{ZrO}_{2}$ catalyst for the CO selective methanation," Chinese Journal of Chemical Engineering, vol. 19, no. 3, pp. 434-438, 2011.

[37] S. B. Wang and G. Q. Lu, "Reforming of methane with carbon dioxide over $\mathrm{Ni} / \mathrm{Al}_{2} \mathrm{O}_{3}$ catalysts: effect of nickel precursor," Applied Catalysis A: General, vol. 169, no. 2, pp. 271-280, 1998.

[38] C. Guimon, A. Auroux, E. Romero, and A. Monzon, "Acetylene hydrogenation over Ni-Si-Al mixed oxides prepared by sol-gel technique," Applied Catalysis A: General, vol. 251, no. 1, pp. 199214, 2003.

[39] M. D. Cai, J. Wen, W. Chu, X. Q. Cheng, and Z. J. Li, "Methanation of carbon dioxide on $\mathrm{Ni} / \mathrm{ZrO}_{2}-\mathrm{Al}_{2} \mathrm{O}_{3}$ catalysts: effects of $\mathrm{ZrO}_{2}$ promoter and preparation method of novel $\mathrm{ZrO}_{2}-\mathrm{Al}_{2} \mathrm{O}_{3}$ carrier," Journal of Natural Gas Chemistry, vol. 20, no. 3, pp. 318324, 2011. 

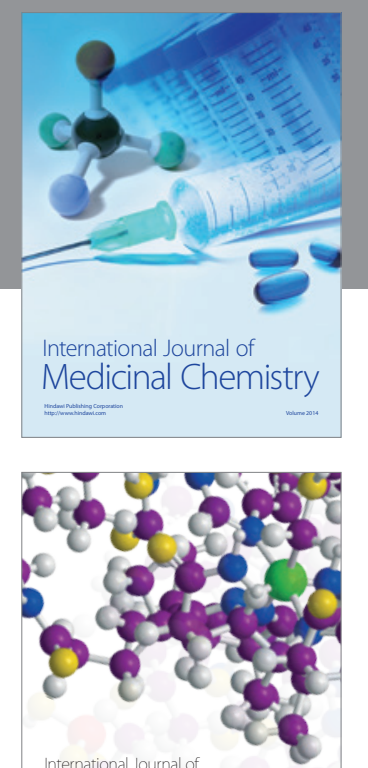

\section{Carbohydrate} Chemistry

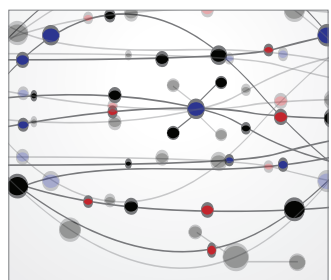

The Scientific World Journal
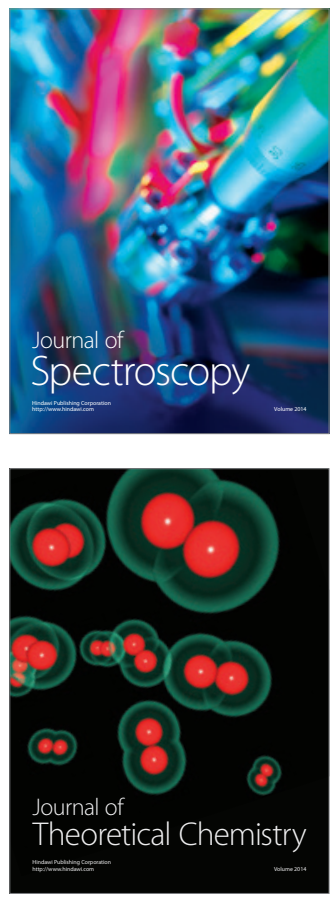
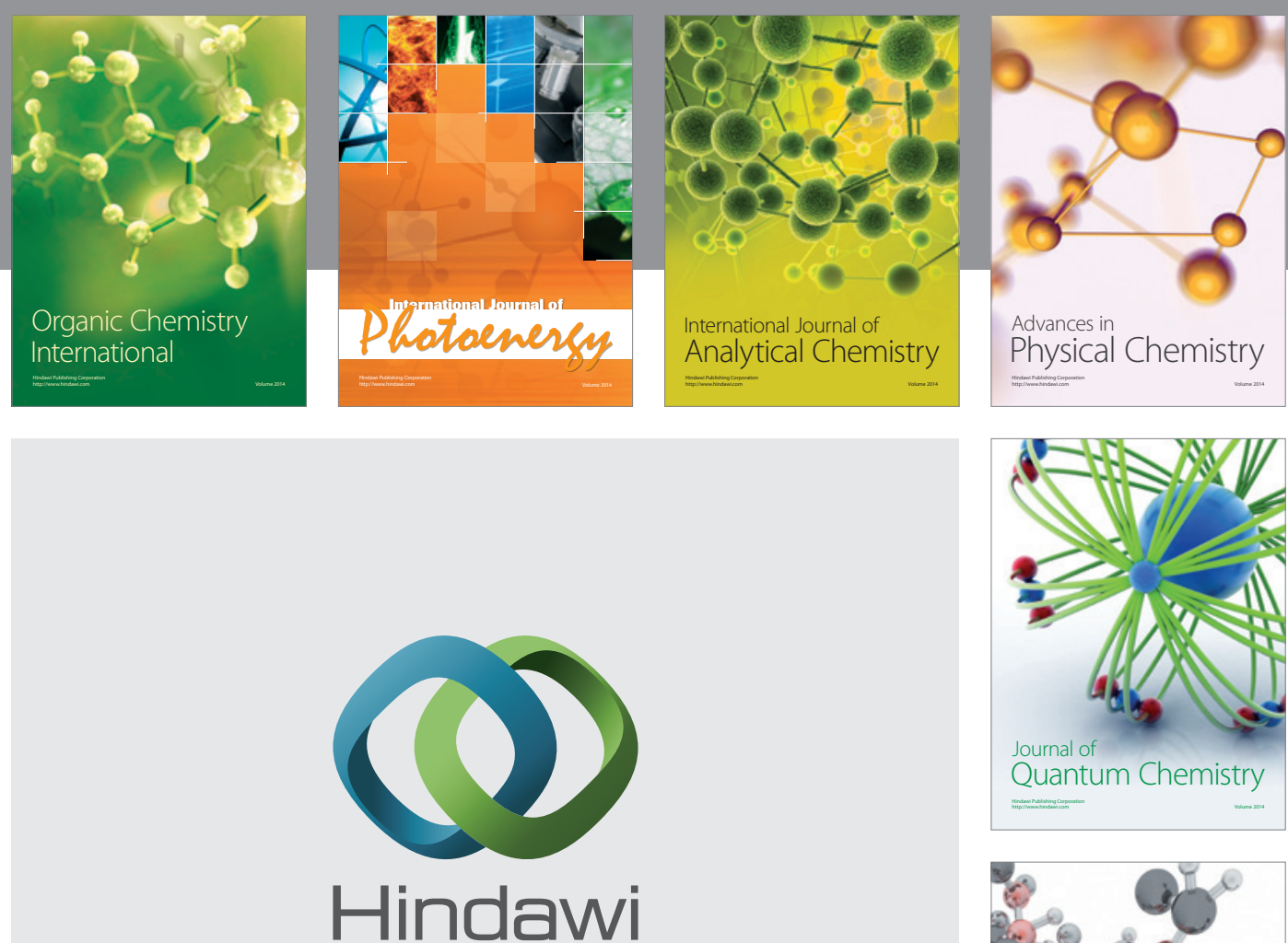

Submit your manuscripts at

http://www.hindawi.com

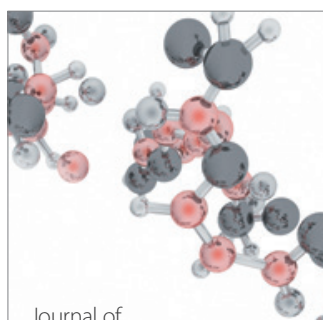

Analytical Methods

in Chemistry

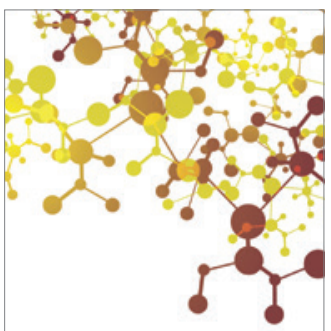

Journal of

Applied Chemistry

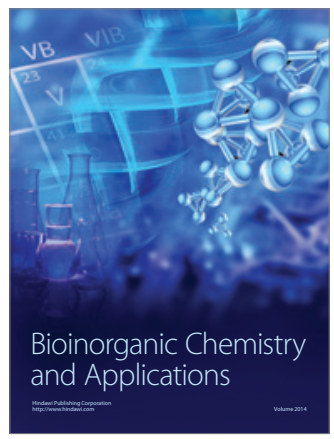

Inorganic Chemistry
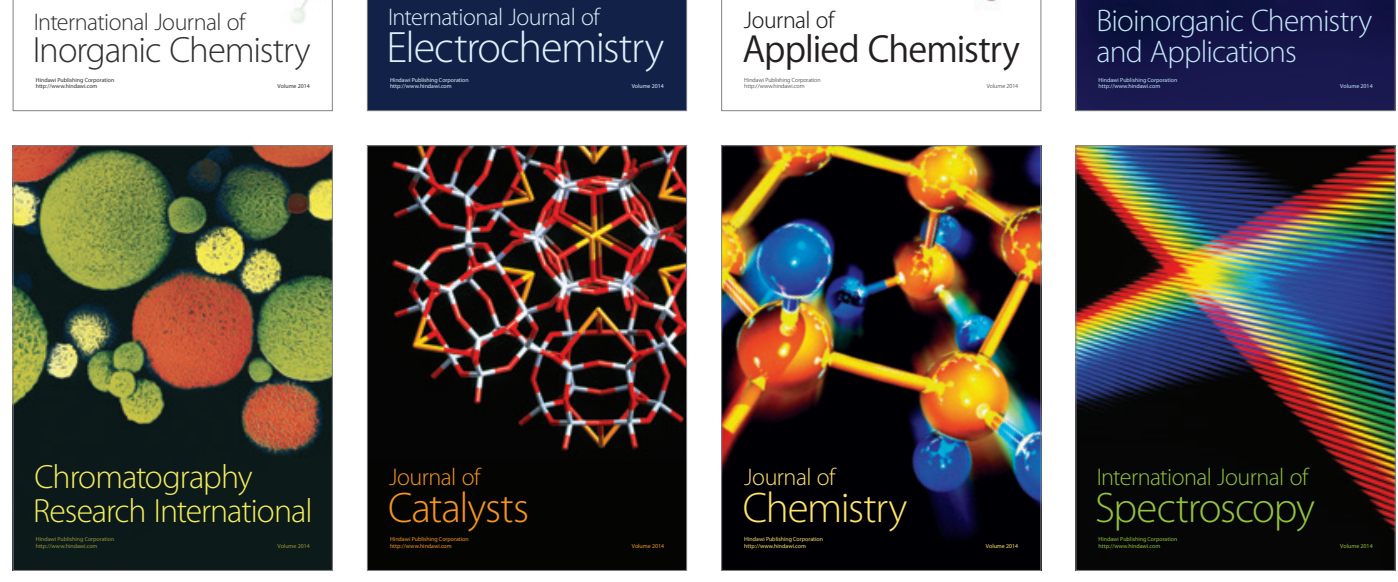